\title{
Bond strength of a resin composite to MTA at various time intervals and with different adhesive strategies
}

\section{Wytrzymałość połączenia żywicy kompozytowej z MTA w różnych przedziałach czasowych i po odmiennym sposobie użycia systemu wiążącego}

\author{
Mia Sulwińska ${ }^{1, A-D}$, Agata Szczesio2, B, C, Elżbieta Bołtacz-Rzepkowska ${ }^{1, D-F}$ \\ ${ }^{1}$ Department of Conservative Dentistry, Chair of Conservative Dentistry and Endodontics, Medical University of Lodz, Łódź, Poland \\ 2 Academic Materials Testing Laboratory, Medical University of Lodz, Łódź, Poland \\ A - research concept and design; $\mathrm{B}$ - collection and/or assembly of data; $\mathrm{C}$ - data analysis and interpretation; \\ $D$ - writing the article; $E$ - critical revision of the article; $F$ - final approval of article
}

Address for correspondence

\section{Mia Sulwińska}

E-mail:mivi@go2.pl

\section{Funding sources}

Medical University of Lodz - grant for young researchers and PhD students no. 502-03/2-044-01/502-24-055

Conflict of interest none declared

Received on December 18, 2016

Revised on March 27, 2017

Accepted on April 19, 2017
DOI

$10.17219 / \mathrm{dmp} / 70545$

\begin{abstract}
Background. MTA cannot be used as a single restorative material due to poor esthetics and mechanical properties. Resin-based composite is often placed on top of MTA. Optimal time of doing that and the most effective bonding strategy have not been clearly determined.

Objectives. The aim of the study was to evaluate the bond strength of a composite to MTA at various time intervals and with different adhesive strategies.

Material and methods. Composite material was bonded to MTA after different time intervals: directly after the placement of MTA (group I), after $24 \mathrm{~h}$ (group II), after $72 \mathrm{~h}$ (group III). Each group was divided into 2 subgroups $(n=15)$ in which a universal bonding system was used respectively: in subgroups $A$ as a total-etch adhesive (TE), in subgroups B as a self-etch (SE). The specimens were subjected to shear bond strength test in a universal testing machine.
\end{abstract}

Results. Statistically significant differences were observed at all time intervals for both bonding protocols TE/SE. In all groups shear bond strength values were higher when the bonding agent was used as a TE vs SE (statistically significant differences in groups I and III). Group II demonstrated the highest bond strength (TE 6.89 MPa; SE 3.82 MPa), followed by group III (TE 5.19 MPa; SE 2.74 MPa) and group I (TE 1.52 MPa; SE $0.74 \mathrm{MPa}$ ) where the bond strength was the lowest.

Conclusions. The shear bond strength of composite to MTA depends on both - time interval between MTA placement and the application of an adhesive system and on the bonding strategy. The highest bond strength was obtained when the adhesive was used after $24 \mathrm{~h}$ in a total-etch technique.

Key words: shear bond strength, composite materials, MTA, adhesive systems

Słowa kluczowe: wytrzymałość połączenia na ścinanie, materiały kompozytowe, MTA, systemy adhezyjne

Copyright

○ 2017 by Wroclaw Medical University

and Polish Dental Society

This is an article distributed under the terms of the

Creative Commons Attribution Non-Commercial License

(http://creativecommons.org/licenses/by-nc-nd/4.0/) 
Mineral Trioxide Aggregate (MTA) is a hydraulic calcium-silicate cement which means that it sets and remains stable in humid environment. ${ }^{1}$ This feature distinguishes it from other materials used in dentistry. MTA is also considered biocompatible and bioactive. ${ }^{2}$ It was initially introduced as a root perforation repair material ${ }^{3}$ and a retrograde filling in apicoectomy. ${ }^{4}$ Thanks to the combination of unique and desirable properties, it has found much wider application in the modern dentistry. ${ }^{5}$

MTA sets during hydration. This process takes place in two steps, which can be divided into preliminary and final setting. During the first stage the material hardens, but complete setting takes much longer. The manufacturer of the first commercially available material of this group (ProRoot ${ }^{\circledR}$ MTA, Dentsply Tulsa Dental Specialties, Johnston City, USA) recommends that the cement be covered with a damp cotton pellet for $4 \mathrm{~h}$ after the application. This is to ensure a sufficient amount of water to the proper course of the reaction. The final setting, according to the manufacturer, occurs within four weeks.

The need to use a moist cotton pellet in the initial phase of the reaction is sometimes questioned because tooth tissues are permeable to water. Budig and Eleazer filled root canals of extracted teeth with dry MTA and found that in $90 \%$ of samples the cement set within $72 \mathrm{~h} .{ }^{6}$ According to the researchers this was possible due to the absorption of water from the root surface.

Clinically, MTA is often in direct contact not only with the tooth structure, but also with restorative materials, e.g. resin-based composites. In many cases, the contact surface of the cement and composite is considerable and, therefore, the bond strength between the materials can substantially affect the final treatment outcome.

Thus far, studies have not given unequivocal answers as to the best time to cover MTA with composite material and the most effective kind of adhesive strategy. Some authors recommended performing the final restoration with a composite material after at least 72-96 h, which is the time when the MTA gains optimal physical properties. ${ }^{7,8}$ Others believe that it is possible to cover MTA with a composite immediately after its application. ${ }^{9,10}$
There is also no consensus as to the type of adhesive strategy which would give the highest bond strength between MTA and composite. Some researchers have shown that the performance of self-etch (SE) is superior to total-etch systems (TE) ${ }^{9}$ contrary to others, who found that TE systems gave higher bond strength than SE. 8,11

The aim of the study was to evaluate the bond strength of a resin-based composite to MTA at various time intervals and with different adhesive strategies.

\section{Material and methods}

The materials used in the study are presented in Table 1 . The method of their application was consistent with the manufacturer's recommendations.

A total of 105 cylindrical acrylic blocks (Villacryl ${ }^{\circledR}$ IT, Zhermapol, Warszawa, Poland) with a central hole of $4 \mathrm{~mm}$ in both, diameter and depth, were prepared. They were stored in distilled water for a week in order to minimize potential subsequent sorption of water from the MTA by the acrylic resin, which could disrupt the setting of MTA. Before the MTA placement the blocks were dried with a three-in-one syringe.

ProRoot MTA was mixed with water supplied by the manufacturer in a $3: 1$ ratio on a glass slab with a metal spatula. The holes in the acrylic blocks were filled with the MTA with slight excess and then leveled with the acrylic block surface with a metal flat plastic instrument. The specimens were divided into 3 groups in which the adhesive system and the composite were applied after various time intervals: in group I - directly after the placement of the MTA, in group II - after $24 \mathrm{~h}$ and in group III - after $72 \mathrm{~h}$.

Each group was further divided into two subgroups - $A$ and $B(n=15$ each). In the subgroups a universal adhesive (Single Bond Universal ${ }^{\circledR}$, 3M ESPE, Neuss, Germany) was applied in a TE strategy. The MTA was etched with 36\% orthophosphoric acid (Arkona, Nasutów, EU) for $15 \mathrm{~s}$, rinsed with the triple syringe for $15 \mathrm{~s}$ and gently air-dried leaving the MTA surface visibly moist. In sub-

Table 1. Materials used in the study

\begin{tabular}{|c|c|c|c|c|}
\hline Material & Composition & Mode of application & Manufacturer & LOT No. \\
\hline Pro $\operatorname{Root}^{\circledR}$ MTA & $\begin{array}{l}\text { tricalcium silicate, bismuth oxide, dicalcium silicate, } \\
\text { tricalcium aluminate, calcium sulfate dehydrate or } \\
\text { gypsum }\end{array}$ & $\begin{array}{l}\text { mix the powder contained in the pouch } \\
\text { with the liquid from the ampoule for } \\
\text { about one minute until a thick, creamy } \\
\text { consistency is obtained }\end{array}$ & $\begin{array}{l}\text { Dentsply Tulsa } \\
\text { Dental Specialities, } \\
\text { Johnston City, } \\
\text { USA }\end{array}$ & 13102906 \\
\hline $\begin{array}{l}\text { Single Bond } \\
\text { Universal }\end{array}$ & $\begin{array}{l}\text { MDP monomer (10-methacryloyloxydecyl } \\
\text { dihydrogen phosphate), dimethacrylate resin, HEMA } \\
\text { (2-hydroksyethyl methacrylate), vitrebond copolymer, } \\
\text { filler, ethanol, water, initiators, silane }\end{array}$ & $\begin{array}{l}\text { rub in for } 20 \mathrm{~s} \text {; evaporate solvent with } \\
\text { gentle stream of air for } 5 \mathrm{~s} \text { until it no } \\
\text { longer moves; light cure for } 10 \mathrm{~s}\end{array}$ & $\begin{array}{l}\text { 3M ESPE, Neuss, } \\
\text { Germany }\end{array}$ & 553960 \\
\hline Filtek ${ }^{\mathrm{TM}}$ Ultimate & $\begin{array}{l}\text { Bis-GMA (bisphenol A diglycidyl ether dimethacrylate), } \\
\text { TEGDMA (triethylene glycol dimethacrylate), reacted } \\
\text { polycaprolactone polymer, substituted dimethacrylate, } \\
\text { nanofillers approx. } 65 \text { \% wt (silane treated ceramic, } \\
\text { silane treated silica, ytterbium fluoride) }\end{array}$ & $\begin{array}{l}\text { apply in layers up to } 2 \mathrm{~mm} \text { trick; light } \\
\text { cure for } 20 \mathrm{~s}\end{array}$ & $\begin{array}{l}\text { 3M ESPE, St. Paul, } \\
\text { USA }\end{array}$ & N735291 \\
\hline
\end{tabular}


groups B, in which the adhesive system was used as a SE, the MTA surface was also rinsed and dried in the same manner except for the subgroup IB, in which the adhesive was applied on the MTA directly after its placement. In all subgroups Single Bond Universal was applied according to manufacturer's instructions and polymerized through the canal of a non-translucent cylindrical silicone matrix with an internal diameter and height of $3 \mathrm{~mm}$. A light-emitting diode light-curing unit (Demi ${ }^{\mathrm{TM}}$ Plus, Kerr, Orange, USA) with an intensity of $1200 \mathrm{~mW} / \mathrm{cm}^{2}$ was used. The canal of the silicone matrix was filled with two layers of flowable composite (Filtek ${ }^{\mathrm{TM}}$ Ultimate shade A2, 3M ESPE, St. Paul, USA). The specimens were covered with moist pre-cut cellulose swabs (Pur-Zellin ${ }^{\circledR}$ $4 \mathrm{~cm} \times 5 \mathrm{~cm}$, Paul Hartman AG, Heidenheim, Germany) and stored at $37^{\circ} \mathrm{C}$ with $>95 \%$ relative humidity.

A control group, in which the composite was placed on top of the MTA without the use of an adhesive, was initially planned. Eventually, it was not included in the study due to pre-test failure in most of the specimens.

The specimens were examined under an operating microscope $24 \mathrm{~h}$ after preparation to ascertain no voids or other defects were present at the composite-MTA interface. They were subjected to the shear bond strength (SBS) test by means of a universal testing machine (Zwick/Roell Z020, Germany) at a crosshead speed of $2 \mathrm{~mm} / \mathrm{min}$.

The experiment was performed by 2 operators: the first one was responsible for the specimen preparation, the other for the testing. After the SBS test, the fractured specimens were examined under a stereomicroscope (Olympus BX51) to evaluate the type of failure (adhesive, cohesive within one of the substrates or mixed).

During the statistical analysis, generalized estimating equations accounting for repeated measurements and with robust standard errors (due to the small sample size) were fitted.

A level of $\mathrm{p}<0.05$ was considered statistically significant. All computations were performed using the Stata ${ }^{\circledR} /$ Special Edition, release 14 package (StataCorp LP, College Station, USA).

\section{Results}

Shear bond strength values of the resin composite to the MTA and the results of the statistical analysis are shown in Table 2 and illustrated in Fig. 1.

Statistically significant differences were found in relation to the time of composite application for both, SE $(\mathrm{p}<0.001)$ as well as, TE technique $(\mathrm{p}<0.001)$. The twoway analysis showed that the intensity of these differences was more powerful for the specimens prepared with the TE strategy as compared to SE ( $\mathrm{p}<0.001)$ (Fig. 1).

Based on the statistical analysis it was also found that in all the groups the SBS was higher for TE technique than SE. The highest SBS was observed in group II, wherein the bonding agent was applied $24 \mathrm{~h}$ after the placement of MTA, lower in group III, in which the adhesive was used after $72 \mathrm{~h}$ and the lowest in group I, where it was applied directly after preparation of MTA. In groups I and III, differences between subgroups (TE and SE) were statistically significant (Table 2).

The highest SBS (6.89 MPa) was observed in subgroup IIA, in which the adhesive was applied $24 \mathrm{~h}$ after MTA placement when the TE strategy was used.

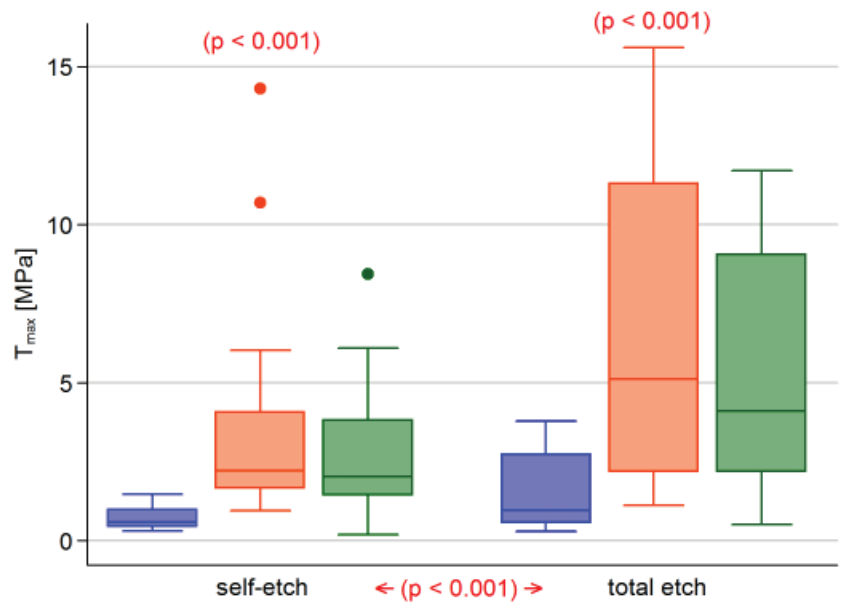

directly after the application $\square$ after 24 hours after 72 hours

Fig. 1. Shear bond strength [MPa] of composite to MTA

Table 2. Descriptive statistics for the shear bond strength values [MPa] in case of the bonding system applied upon the MTA by time after application and adhesive strategy

\begin{tabular}{|c|c|c|c|c|c|c|c|}
\hline \multirow[b]{2}{*}{ Groups } & \multirow[b]{2}{*}{ Subgroups } & \multicolumn{5}{|c|}{ Statistical parameter } & \multirow{2}{*}{$\begin{array}{l}\text { Differences } \\
\text { between } \\
\text { groups, level } \\
\text { of statistical } \\
\text { significance "p" }\end{array}$} \\
\hline & & $\frac{M}{\text { mean value }}$ & $\begin{array}{c}\text { SD } \\
\text { standard } \\
\text { deviation }\end{array}$ & $\begin{array}{l}\text { SE } \\
\text { standard } \\
\text { error }\end{array}$ & $\begin{array}{c}95 \% \mathrm{Cl} \\
\text { confidence } \\
\text { interval }\end{array}$ & $\begin{array}{c}\text { CV } \\
\text { coefficient } \\
\text { of variation }\end{array}$ & \\
\hline \multirow{2}{*}{$\begin{array}{l}\text { Directly after } \\
\text { the application }\end{array}$} & IA (total-etch) & 1.515 & 1.218 & 0.315 & $0.840-2.190$ & $80.44 \%$ & \multirow{2}{*}{0.018} \\
\hline & IB (self-etch) & 0.741 & 0.390 & 0.108 & $0.505-0.976$ & $52.68 \%$ & \\
\hline \multirow{2}{*}{ After $24 \mathrm{~h}$} & IIA (total-etch) & 6.893 & 5.249 & 1.355 & $3.986-9.800$ & $76.16 \%$ & \multirow{2}{*}{0.061} \\
\hline & IIB (self-etch) & 3.813 & 3.793 & 0.979 & $1.712-5.913$ & $99.47 \%$ & \\
\hline \multirow{2}{*}{ After $72 \mathrm{~h}$} & IIIA (total-etch) & 5.190 & 3.656 & 0.944 & $3.166-7.215$ & $70.44 \%$ & \multirow{2}{*}{0.023} \\
\hline & IIIB (self-etch) & 2.740 & 2.150 & 0.555 & $1.549-3.930$ & $78.49 \%$ & \\
\hline
\end{tabular}




\section{Discussion}

ProRoot MTA is the first bioceramic material approved for the use in endodontics. ${ }^{12}$ Nowadays, there are many other materials of similar composition and properties: hydraulic calcium silicate cements and calcium phosphate silicate cements. ${ }^{13}$ ProRoot MTA was chosen for this study, as it still remains the material of choice for many practitioners due to the availability of long-term clinical observations.

Only a few studies have tested the shear bond strength of resin composite to this material. They compared various adhesive systems of different generations ${ }^{8,9,11,14}$ Their results show which of the bonding systems used is better in comparison to the others, but it is hard to make a conclusion as to which adhesive technique is better. The differences in bond strength among the tested groups could have been caused by the bonding strategy as well as different ingredients of the adhesives. ${ }^{9,11}$

To eliminate the composition of the bonding system as a variable, we chose to use a universal adhesive, which according to the manufacturer, may be used in the SE or TE technique. Furthermore, a study by Thanaratikul et al. ${ }^{15}$ shows that there were no statistically significant differences in the SBS of a composite bonded dentin with Single Bond Universal irrespective of prior etching of the dentin, which proves that, at least in the case of bonding to dentin, the adhesive is equally effective in both strategies $-\mathrm{SE}$ and TE.

Even fewer studies investigated the influence of the time interval between MTA placement and covering it with composite on the SBS between these materials. ${ }^{8,9}$ Atabek et al. ${ }^{8}$ placed a composite over the MTA after 4 , 24, 48, 72 and 96 h, Neelakantan et al. ${ }^{9}$ - immediately, after $45 \mathrm{~min}$ and $24 \mathrm{~h}$. According to Atabek at al. it is best to postpone the final restoration for at least $96 \mathrm{~h}$ after mixing MTA, although the SBS after $72 \mathrm{~h}$ and $96 \mathrm{~h}$ was similar. ${ }^{8}$ Their recommendation seems to be based on previous study by Kayahan et al., who investigated the effect of acid-etching of MTA 4, 24, and $96 \mathrm{~h}$ after the application on its microhardness and compressive strength. ${ }^{7}$ The authors found that when MTA was etched $4 \mathrm{~h}$ after its placement the compressive strength declined. There were no statistically significant differences in the groups etched after 24 and $96 \mathrm{~h}$ as compared to the control groups in which MTA was not etched. In all the tested groups etching caused a decrease of the MTA microhardness. It was relatively the highest in the group that was etched after $96 \mathrm{~h}$ which is the reason why the authors recommended to continue restorative procedures after that time, to allow MTA 'to achieve its optimum physical properties.'

On the contrary, Neelakantan et al., based on the results of their study, claimed that composite might be placed over MTA immediately. ${ }^{9}$ This is when they achieved the highest SBS values. From the clinical point of view, that would be advantageous, as it would eliminate the neces- sity to prolong the treatment. It would also minimize the potential risk of coronal leakage, which in turn could be hazardous to the treatment outcome.

In our study, we chose the time intervals in a way that would let us compare the results with the studies mentioned above. ${ }^{8,9}$ The results of our experiment did not confirm that an immediate composite placement gives high SBS values (SE - 0.74 MPa, TE - 1.52 MPa). The SBS was considerably higher when the composite was applied after $24 \mathrm{~h}(\mathrm{SE}-3.81 \mathrm{MPa}, \mathrm{TE}-6.89 \mathrm{MPa})$ or after $72 \mathrm{~h}$ $(\mathrm{SE}-2.74 \mathrm{MPa}, \mathrm{TE}-5.19 \mathrm{MPa})$. The number of layers of the adhesive used could have accounted for the differences between the studies of Neelakantan et al. and ours (respectively, 3 layers of the adhesive and 1 were applied). ${ }^{9}$

We also found statistically significant differences between the time groups in which the bonding system was applied after 24 or $72 \mathrm{~h}$. The SBS was higher in the 24-h group. This is inconsistent with the study of Atabek et al., in which the SBS after $72 \mathrm{~h}$ was approximately twice as high as that after $24 \mathrm{~h}$ for the three adhesive systems used. ${ }^{8}$

Several elements could have caused these discrepancies. Firstly, we used an adhesive that was not tested in other studies. Among the factors connected with the composition of the bonding system, which are likely to affect the SBS of a composite to MTA, the following are most often considered: the type of solvent, the presence of HEMA, the presence of mixture of hydrophilic and hydrophobic monomers in one-step systems (VII generation) and the $\mathrm{pH}$ of $\mathrm{SE}$ adhesives. It seems that the effect of these composition-related factors should be the same as for the bonded tooth structure but in relation to MTA it has not been confirmed yet.

Secondly, in the studies of Atabek et al. ${ }^{8}$ and Neelakantan et al., ${ }^{9}$ contrary to our study, the MTA surface was neither rinsed nor dried before the application of the bonding system. Tsujimoto et al. observed the interface between MTA and a composite with a scanning electron microscope and they measured the microhardness of MTA after composite placement. ${ }^{10}$ In their study, after the application of MTA they used a temporary filling which subsequently had to be removed. In order to clean the MTA surface of the remnants of the provisional cement they used the air from the triple syringe. They noticed a negative influence of drying on the microhardness of MTA. In our study, a temporary filling was not used, but clinically, when a provisional restoration is removed a certain amount of dust and particles of the material usually stays in the treated tooth. The easiest way to remove the debris is to rinse them out. That is the reason why we decided to rinse and dry the MTA, while leaving the surface visibly moist.

Rinsing of MTA may influence the material differently depending on the stage of the setting reaction. It has been reported that in the first $72 \mathrm{~h}$ the solubility and the risk of dislodgement of MTA is increased. ${ }^{16,17}$ Therefore, in our experiment, we directed the stream of water on the acrylic 
block rather than straight on the MTA surface. We did not observe dissolution of MTA even in the subgroup IA in which the TE system was applied immediately. However, it was visible that the surface of the MTA was disintegrating while the adhesive was being applied, especially in the SE group (IB).

The third difference was the crosshead speed used. In our study it was $2 \mathrm{~mm} / \mathrm{min}$ while in the other studies it was $1 \mathrm{~mm} / \mathrm{min}$. Some research shows that the crosshead speed influences the results of the SBS tests, other does not confirm that. ${ }^{18,19}$

In the previous research on the changes in the bond strength of composite to MTA, depending on the time of composite placement, it was suggested that changes in the porosity of MTA during its setting may have an impact on the bond strength. Initially, the MTA is more porous so there are more microretentions available for the adhesive system. Consequently, the bond strength is also higher. While setting, the porosity decreases as well as the bond strength. ${ }^{9}$ That could explain why the SBS after $72 \mathrm{~h}$ was lower than after $24 \mathrm{~h}$ in our study.

On the other hand, the previous research, except for the study by Neelakantan et al. ${ }^{9}$, reports a majority of cohesive failures within the MTA in the specimens subjected to SBS test. ${ }^{8,20,21}$ One possible interpretation of this is that the adhesion of composite to MTA is higher than the cohesion of MTA. During the setting process the mechanical properties of MTA improve which may lead to the growth in SBS. ${ }^{21}$

In our study, most of the fracture modes observed were cohesive within the MTA with only few mixed failures and no adhesive. At the time when the specimens belonging to group I (where the bonding system was applied immediately after MTA placement) were tested, the physical properties of MTA were not yet optimal. That is possibly the reason why the results in that group were the lowest.

Considering the adhesive strategy, in all the groups of our study, the SBS was higher when the TE technique was used as opposed to SE. It is believed that orthophosphoric acid and $\mathrm{SE}$ systems of low $\mathrm{pH}$ may weaken the structure of MTA to a higher degree than those with a higher $\mathrm{pH} .{ }^{9,22}$ The $\mathrm{pH}$ of the bonding system used in our study is 2.7 , so it is a mild SE. Theoretically, if the $\mathrm{pH}$ were a determining factor, the SBS would have been higher in the SE than in TE subgroups. The results of our studies do not confirm the presence of the correlation between the $\mathrm{pH}$ of an adhesive used to bond composite with MTA and the SBS. It is consistent with the observations of Bayrak et al., whose results also question the presence of such correlation. ${ }^{22}$

The fracture analysis revealed that most failures in our study were cohesive within the MTA as we have already mentioned. In such case the results of the SBS test are being questioned, because it seems that it is not really the interface between the materials that is tested. On the other hand, the differences in the results among the groups and subgroups are clearly visible. This may be explained in the following way. A fracture usually starts in a place where a flaw of the material is present - it may be a porosity or non-homogenous structure. When the adhesive is used it penetrates the porosities of MTA and prevents the propagation of the fracture to a different degree depending on the bonding technique. ${ }^{23,24}$ That would suggest that the use of TE strategy guarantees deeper penetration of the adhesive into MTA structure and strengthens it more than when SE technique is used.

Within the limitations of our study, it can be concluded that the shear bond strength of composite to MTA depends on both - time interval between MTA placement and the application of adhesive system and on the bonding strategy. The highest bond strength was obtained when the adhesive was used after $24 \mathrm{~h}$ in a total-etch technique.

\section{References}

1. Darvell BW, Wu RCT. "MTA" - an hydraulic silicate cement: Review update and setting reaction. Dent Mater. 2011;27:407-422.

2. Torabinejad M, Parirokh M. Mineral trioxide aggregate: A comprehensive literature review - part II: Leakage and biocompatibility investigations. J Endod. 2010;36:190-202.

3. Lee SJ, Monsef M, Torabinejad M. Sealing ability of a mineral trioxide aggregate for repair of lateral root perforations. J Endod. 1993;19:541-544.

4. Torabinejad M, Watson TF, Pitt Ford TR. Sealing ability of mineral trioxide aggregate when used as a root end filling material. J Endod. 1993;19:591-595.

5. Haapasalo M, Parhar M, Huang X, Wei X, Lin J, Shen Y. Clinical use of bioceramic materials. Endod Topics. 2015;32:97-117.

6. Budig CG, Eleazer PD. In vitro comparison of the setting of dry ProRoot ${ }^{\circledR}$ MTA by moisture absorbed through the root. $J$ Endod. 2008;34:712-714.

7. Kayahan MB, Nekoofar MH, Kazandağ M, et al. Effect of acid-etching procedure on selected physical properties of mineral trioxide aggregate. Int Endod J. 2009;42:1004-1014.

8. Atabek D, Sillelioğlu H, Ölmez A. Bond strength of adhesive systems to mineral trioxide aggregate with different time intervals. J Endod. 2012;38:1288-1292.

9. Neelakantan P, Grotra D, Subbarao CV, Garcia-Godoy F. The shear bond strength of resin-based composite to white mineral trioxide aggregate. J Am Dent Assoc. 2012;143:e40-e45.

10. Tsujimoto $M$, Tsujimoto $Y$, Ookubo A, et al. Timing for composite resin placement on mineral trioxide aggregate. J Endod. 2013;39:1167-1170.

11. Tunç ES, Sönmez IS, Bayrak S, Eğilmez T. The evaluation of bond strength of a composite and a compomer to white mineral trioxide aggregate with two different bonding systems. J Endod. 2008;34:603-605.

12. Torabinejad $M$, White DJ. Tooth filling material and method of use. United States Patent. 1995. 5415547.

13. Shen Y, Peng B, Ma J, Haapasalo M. What do different tests tell about the mechanical and biological properties of bioceramic materials? Endod Topics. 2015;32:47-85.

14. Jaberi-Ansari Z, Mahdilou M, Ahmadyar M, Asgary S. Bond strength of composite resin to pulp capping biomaterials after application of three different bonding systems. J Dent Res Dent Clin Dent Prospects. 2013;7:152-156.

15. Thanaratikul B, Santiwong B, Harnirattisai C. Self-etch or etch-andrinse mode did not affect the microshear bond strength of a universal adhesive to primary dentin. Dent Mater J. 2016;35:174-179.

16. Vanderweele RA, Schwartz SA, Beeson TJ. Effect of blood contamination on retention characteristics of MTA when mixed with different liquids. J Endod. 2006;32:421-424.

17. Bodanezi A, Carvalho N, Silva D, et al. Immediate and delayed solubility of mineral trioxide aggregate and Portland cement. J Appl Oral Sci. 2008;16:127-131 
18. Hara AT, Pimenta LAF, Rodrigues Jr AL. Influence of crosshead speed on resin-dentin shear bond strength. Dent Mater. 2001:17:165-169.

19. de Abreu CW, Duarte Filho G, Kojima AN, Jóias RM, Mesquita AMM. Evaluation of crosshead speed influence on shear bond strength test. Braz Dent Sci. 2014;17:50-53.

20. Oskoee SS, Kimyai S, Bahari M, Motahari P, Eghbal MJ, Asgary S. Comparison of shear bond strength of calcium-enriched mixture cement and mineral trioxide aggregate to composite resin. J Contemp Dent Pract. 2011;12:457-462.

21. Ajami AA, Navimipour EJ, Oskoee SS, Kahnamoui MA, Lotfi M, Daneshpooy M. Comparison of shear bond strength of resin-modified glass ionomer and composite resin to three pulp capping agents. J Dent Res Dent Clin Dent Prospects. 2013;7:164-168.

22. Bayrak Ş, Tunç EŞ, Şaroglu I, Eğilmez T. Shear bond strengths of different adhesive systems to white mineral trioxide aggregate. Dent Mater J. 2009;28:62-67.

23. Braga RR, Meira JB, Boaro LC, Xavier TA. Adhesion to tooth structure: a critical review of "macro" test methods. Dent Mater. 2010;26:e38-e49.

24. Sultan H, Kelly JR, Kazemi RB. Investigating failure behavior and origins under supposed "shear bond" loading. Dent Mater. 2015;31:807-813. 